\title{
THE MURDOCH BICENTENARY
}

$\mathrm{T}$ HIS year marks the bicentenary of the birth of William Murdoch (1754-1839), the originator of gas lighting. For that great achievement alone he would stand out as a great figure in the history of progress, yet it was only one of his many inventions. The story of his life should serve as an incentive and example to every scientific worker. Possibly forgotten is the incident of the wooden hat which brought about his association with Matthew Boulton and James Watt, and his opportunity for achieve. ment. After having walked all the way from his home in Ayrshire to the now famous Soho Works in Birmingham, he might have been turned away by Boulton had not Murdoch dropped his wooden hat at the prospective employer's rebuff. Boulton noticed, however, the unusual character of his headgear, questioned him about it, and learnt that he was the inventor of the oval lathe with which he had made it. That was the beginning of the famous triple partnership.

As a boy, Murdoch had made himself 'a wooden horse' for his journeys to school, a distance of $2 \frac{1}{2}$ miles; it was the forerunner of the tricycle and the bicycle, which only became a practical reality many years later. This experience ultimately led him to construct a model non-condensing locomotive stearnengine, now in the Birmingham Art Gallery; but his attempts to patent it were, strangely enough, opposed by Watt. An entrancing story of these early beginnings and his many other remarkable inventions has been recently published in West's Gas, the house journal of West's Social Society, from the pen of his great-grand-niece, Margaret L. Murdoch. Attractive, too, is the 1954 Murdoch Memorial Lecture of the Institution of Gas Engineers, under the distinguished authorship of no less a person than the chairman of Imperial Chemical Industries, Ltd., Dr. Alexander Fleck. Therein has been paid a fitting tribute to Murdoch's memory in a very informative account of the origins and development of gas for industrial purposes, viewed from the angle of an organization which has, above all others, so successfully applied the service of gas to the chemical industry. It is, in Dr. Fleck's words, a record "of the development of a great concert of industrial processes - today as powerful and as full of promise as ever before to make available the things we value in our way of living".

In effect, gas becomes increasingly a great source of chemicals. The vast output of ammonia and nitric acid for chemical manufacture and explosives are the products of a synthesis which begins with the gasification of coke, and the production of hydrogen and carbon monoxide, as water gas. The same process is the starting point of that remarkable synthesis of hydrocarbons and the complex series of by-products associated with the Fischer-Tropsch process, so actively applied to the German economy in the Second World War. From the same origins, with benzene, is produced nylon. From the hydrogenolysis of natural oils and fats arise higher alcohols, solvents and plasticizers, to mention but a limited range of many wonders.

To turn to the wider needs of the fuel industries, there must ultimately come an urgent and crying demand for the greater application of total gasification in the gas and heavy industries, for the supplies of good coking coals are showing signs of exhaustion, and processes must be devised to utilize weakly and non-caking coals. The 'smog' problem also points out the same objective. With the provision of cheap gas for industry, the efficiency and adaptability of many types of heating and processing plant become greatly advanced. A process for the cheap production of oxygen would expedite all the prospective developments in this field. That the gasification of oil may also serve as a useful adjunct to the processes based on coal may be envisaged with a measure of certainty. In the pursuit of these objectives, reference to the example of Murdoch's career may be timely-to the example of his energy and persistence in an age when technical skills were weak and groping, under rebuffs and disappointments such as the opposition of no less a person than Watt. But for this opposition, Murdoch's locomotive would have been an accomplished fact nearly half a century before Stephenson's, and a quarter of a century before Trevethick's. Indeed, as a boy, Trevethick had been a frequent visitor to Murdoch's home at Redruth, and must have seen him at work on his engine. It is said that, Trevethick purchased the model from the disappointed inventor. Murdoch has been called "the incomparable mechanic" ; further, we must recognize what an amazing achievement has emerged from disappointment and effort.

R. J. SarJanT

\section{THE HEALTH OF CHILDREN}

A

NEW exhibition at the Wellcome Historical Medical Museum, at 28 Portman Square, London, W.1, deals with "The Child Through the Ages" and illustrates by means of skilfully selected objects, books and prints the methods which have been used to feed, clothe and transport the young child from early times. It also shows the development of the idea that disease in the child is often so different from that in the adult as to warrant the creation of the specialty later termed 'pædiatrics'. This exhibition covers the whole field from the earliest times to the beginning of the present century. It contains many objects of great beauty, and is worthy of the traditions of the Wellcome Museum.

It is well known that the Museum possesses a very fine collection of effigies of ancient Egyptian gods, and a few of these are shown in this exhibition. In the classical period of Greece and Rome the emphasis is rather on the portrayal of the mother with her child. Third-dimensional art had become fully representational, and the artists found in this theme a congenial subject. Some of these third-century B.c. terra cottas show a gracefulness of line which often escapes more ambitious compositions. The marble bas-relief from Ostia of a mother suckling her child exhibits a different treatment from that used in the Greek figures, and is also noteworthy.

During the medieval period, the attitude of the Christian Church resulted in the cult of certain saints who were especially concerned with the care of children. This attitude is exemplified by several very interesting Breton effigies in wood, dating from the 